TARNOWSKIE STUDIA TEOLOGICZNE 36 (2017) NR 1, S. 155-164

http://dx.doi.org/10.15633/tst.2329

ks. Janusz Królikowski

UNIWERSYTET PAPIESKI JANA PAWŁA II W KRAKOWIE

\title{
Wystąpienie dziekana \\ Wydziału Teologicznego Sekcja w Tarnowie w czasie inauguracji w dniu 6 października 2016 roku
}

Inauguracja nowego roku akademickiego jest zazwyczaj połączona ze sprawozdaniem za rok ubiegły. Konkretne fakty, które naznaczyły życie, działalność i rozwijanie się naszego środowiska akademickiego, zostaną zamieszczone na stronie internetowej i tam odsyłam zainteresowanych. Nie zachodzi tutaj potrzeba chwalenia się podejmowanymi działaniami, osiągnięciami i liczbami, które bezdusznie miałyby je zilustrować. Myślę, że zrobiliśmy dość dużo jako universitas magistorum et scholarium, którą jest Wydział Teologiczny Sekcja w Tarnowie Uniwersytetu Papieskiego Jana Pawła II w Krakowie. Z niewątpliwych osiągnieć chcę wspomnieć tylko dwa: nasz kolega ks. Henryk Szmulewicz uzyskał tytuł profesora nauk teologicznych. Gratulujemy! Natomiast ks. Marek Kluz został zatrudniony na stanowisku profesora UPJPII.

Zamiast jednak przedstawienia osiągnięć, proponuję spojrzenie na rozpoczynany nowy rok akademicki jako przestrzeń naszego powołania i zadania, które podejmujemy z ufnością i głębokim przekonaniem, że chodzi o rzecz ważną dla Kościoła i świata, a tym samym ważną także dla nas osobiście. Spójrzmy więc na cztery wymiary naszego zadania akademickiego, które dzisiaj uroczyście na nowo podejmujemy. Te wymiary to: zaangażować się intelektualnie, poświęcić się misji inteligencji, wędrować pokornie, żyć hojnie z otwartymi oczami. Można powiedzieć, dystansując się oczywiście od rozumienia zaproponowanego przez Spinozę, że chodzi w tym przypadku o wymiary autentycznej „miłości intelektualnej”. Pamiętamy o tym, co mówi św. Tomasz z Akwinu: „In spirituali vita perfectus est, qui in caritate perfectus est”. Ten więc intelektualista jest doskonały, który jest doskonały w miłości. 


\section{Zaangażować się intelektualnie}

Zaangażowanie intelektualne jest naszą wspólną perspektywą - naszą to znaczy nauczycieli akademickich i studentów, i to będzie nasz codzienny obowiązek przez kolejne miesiące. Praca intelektualna, na którą składają się nauczanie, badanie, studium i dyskusja, jest racją bytu uczelni wyższej. Racją bytu naszej uczelni jest kultywowanie inteligencji w najwłaściwszym znaczeniu tego słowa. Chodzi o poważny obowiązek, ponieważ pierwszym obowiązkiem ludzkiej inteligencji, obowiązkiem wynikającym z natury rzeczy - i a fortiori inteligencji chrześcijańskiej - jest myślenie, refleksja, zgłębianie, szukanie, tworzenie itd. Wiemy dobrze, że wiara chrześcijańska w niczym nie pomniejsza i nie ogranicza potencjalności rozumu ludzkiego, ale go pobudza do czynnego sięgania coraz dalej, aż do nieskończoności i do Nieskończonego, a w ten sposób ukierunkowuje ludzką egzystencję na coraz pełniejsze poznanie prawdy, na zdecydowane i przekonane wybieranie większego dobra i na zachwycanie się blaskiem i harmonią piękna.

Zaangażowanie intelektualne nie oddala od świata. Nie możemy iść naprzód z przymrużonymi lub zamkniętymi oczami, z zatkanymi uszami, nie możemy być zamroczeni wobec codziennych wydarzeń lub pozostać narcystycznymi widzami, którzy dostrzegają na swoim horyzoncie tylko siebie i swoje sprawy. Musimy być obecni w naszym czasie i słuchać pytań, jakie stawiają nam współczesne tragedie i niesprawiedliwości, bolesne konflikty i niekończące się dramaty, wołania osób, które potrzebują kogoś, kto ośmieli się widzieć, słuchać i działać. Zaangażować się intelektualnie oznacza być w pierwszym szeregu tych, którzy wiedzą, co to jest odpowiedzialność moralna, którzy nie boją się myśleć o naszej sytuacji historycznej i duchowej, którzy pamiętają, że istnieje determinacja inteligencji i siła wiary, niepozwalające pogodzić się ze stanem faktycznym i uznać go za wprawdzie fatalną, ale przecież konieczność.

$\mathrm{Z}$ tych racji nasze zaangażowanie intelektualne musi być pełne zapału. Potrzeba ognia wewnętrznego, by całościowo podjąć wskazane zagadnienia i natarczywie budzące się pytania, gdyż tylko w ten sposób będzie można zaprezentować odpowiadające im postawy i tylko w ten sposób zostaną rozproszone coraz bardziej gromadzące się na horyzoncie ciemne chmury. Chodzi więc o zaangażowanie gorliwe, by odwołać się do niedocenianej dzisiaj postawy, ponieważ dobrze znamy ciężar trudności i powagę wyzwań, od których nie możemy uciec jako ludzie i jako chrześcijanie. Takie 
zadanie prowadzi nas do bardziej wewnętrznego rozumienia i do bardziej zaangażowanej refleksji, która zawsze dystansuje się od ciasnoty myślenia naznaczonego lękiem i od hałaśliwości tych, którzy uważają, że już wiedzą wszystko i wiedzą najlepiej.

\section{Poświęcić się misji inteligencji}

W grę wchodzi więc poświęcenie się misji inteligencji ludzkiej i chrześcijańskiej w dzisiaj naszego świata. Chodzi o inteligencję otwartą, która nie boi się szerszych horyzontów - jeśli czegoś się boi, to ciasnoty. Chodzi o inteligencję głęboką, która nie boi się sięgania do istoty zagadnień - jeśli czegoś się boi, to powierzchowności. Chodzi o inteligencję w stanie wędrówki, pójścia dalej - jeśli czegoś się boi, to zniewolenia przez to, co bezpośrednio się narzuca i co jest tylko pozorne. Chodzi o inteligencję odważną, która nie boi się pójścia także pod prąd - jeśli czegoś się boi, to utartych schematów, które nie służą rozeznaniu intelektualnemu. Chodzi o inteligencję wierną temu, co ją porusza wewnętrznie - jeśli czegoś się boi, to lenistwa w przekraczaniu swoich ograniczeń. Chodzi w końcu o inteligencję kreatywną, która nie boi się podejmowania nowych zagadnień i wchodzenia na teren nowych dziedzin - jeśli czegoś się boi, to jałowości intelektualnej i uśpienia rozumu.

Poświęcenie się misji intelektualnej zakłada zgodzenie się na to nawrócenie intelektualne, które nigdy nie jest zakończone i za którego podjęcie każdy ma czuć się odpowiedzialny; oznacza pozwolenie, by Bóg, samo Poznanie i sama Prawda, nawrócił naszą inteligencję, ażeby mogła wypełnić swoją wzniosłą misję, ostatecznie wypełniającą się w miłości.

\section{Wędrować pokornie}

Pokora jest znakiem i pieczęcią prawdziwej inteligencji. Autentyczna praca intelektualna ma to do siebie, że nigdy się nie kończy, ponieważ chodzi w niej o sięganie coraz dalej i coraz głębiej, przekraczanie swoich ograniczeń i granic badanej rzeczywistości. Horyzont pracy intelektualnej ma to do siebie, że stale się poszerza. W tej nigdy niekończącej się wędrówce może narodzić się głęboka myśl, dalekowzroczna, a więc pokorna.

Pokora w zaangażowaniu intelektualnym musi być także naznaczona wspomnianym już zapałem. Zapał rodzi się w sercu, wyzwalając wewnętrzny strumień miłości i prowadząc do granic, tam, gdzie rozumie się to, co domaga 
się naszego wysiłku i pójścia za Jezusem Chrystusem po nowych drogach jutra. Zapał jest płomieniem serca inteligentnego. Bez zapału wędrówka intelektualna stałaby się szybko włóczeniem się po utartych ścieżkach, przemieniając się w zimny intelektualizm, często wprost lodowaty, czyli kończyłaby się na manowcach poznania. Zapał wyraża tę energię duchową, która pobudza do wyjścia z siebie i z tego wszystkiego, co więzi ducha i duszę. Ta pokorna wędrówka jest wymogiem, aby żyć w sposób najbardziej osobisty, ale - muszę to w tym miejscu podkreślić - członkowie instytucji akademickiej muszą wędrować także wspólnie, wspólnie szukając prawdy i wspólnie dzieląc się jej efektami. Średniowieczni mistrzowie duchowi podkreślali, że do prawdy najowocniej zmierza się w klimacie „słodyczy przyjaźni”. Tylko dystansując się w stosunku do wszelkiego indywidualizmu i autoreferencyjności, będziemy mogli skutecznie „obronić nadzieję, która jest w nas" (por. 1 P 3, 15).

\section{Żyć hojnie z otwartymi oczami}

Słowo „hojność” może wydawać się trochę napuszone, ale jest ono ważne, niemal narzucające się w proponowanym dyskursie, ponieważ wykracza poza wszelkie wyrachowanie i podkreśla, że nie można się oszczędzać. Słowo „hojność” wydaje mi się znaczące z wielu racji w środowisku akademickim, a szczególnie dlatego, że jesteśmy powołani do życia we wzajemnych relacjach, w których weryfikuje się nasza praca i nasz trud, i które są gwarancją faktycznego dojścia do wspomnianych na początku osiągnięć. Relacyjność akademicka pobudza nas do ciągłego dialogu, to znaczy do słuchania i mówienia, do uczenia się od innych, dzielenia się z innymi tym, co posiadamy, do wzajemnego szacunku.

Taka hojność domaga się otwarcia oczu na to, co nas otacza, czym żyjemy i czym żyją inni. Powinniśmy prosić Ojca niebieskiego o hojną inteligencję, o inteligencję wolną od wszelkich więzów i zdolną do przekraczania wzajemnych uprzedzeń. Kościół i świat potrzebują inteligencji, która będzie dążyła do coraz lepszego zrozumienia słowa Bożego, do ewangelicznego „wypłynięcia na głębię” (por. Łk 5, 4). Wypłyń na głębię, a zrozumiesz więcej, a w ten sposób więcej będzie rozumiał także Kościół i świat. Jeśli wypłyniemy na głębię, będziemy mogli w końcu powiedzieć naszemu Bogu: „Doświadczyliśmy, jak Twój Duch działa w każdym miejscu i w każdej sytuacji, w pracy, w studium, w nauczaniu, w głębi ludzkiego życia i w naszych 
dziejach. Chcemy studiować, nauczać, szukać, oddając się do dyspozycji Kościołowi i światu, aby służyć Tobie i otworzyć Twoją drogę do serca i inteligencji każdego człowieka. Ty wiesz, że chcemy być całkowicie poświęceni Twojej misji i obecni z Tobą w sercu świata. To pragnienie, opromienione Twoją łaską, niech nam dalej towarzyszy i każdego dnia budzi się na nowo". Zaangażować się intelektualnie, poświęcić się misji inteligencji, wędrować pokornie i żyć hojnie z otwartymi oczami - cztery aspekty naszej wspólnej misji, którą chcemy realizować w czasie nowego roku akademickiego 2016-2017, który otwieramy z Bogiem i dla Jego chwały, służąc zbawieniu człowieka za pośrednictwem filozofii i teologii, która jest scientia salutis wiedzą zbawienia. W ten sposób - jak wyjaśnia św. Tomasz z Akwinu - możemy w prawdzie stawać się ewangelicznym „światłem świata”.

„Quod bonum, felix, faustum, fortunatumque sit!" - oby to było dla dobra, szczęścia i pomyślności! 



\section{Prace doktorskie, licencjackie i magisterskie w roku akademickim 2015-2016}

\section{Doktoraty}

ks. mgr lic. Marcin Krępa, Recepcja wskazań Soboru Watykańskiego II dotyczących odnowy muzyki sakralnej. Studium liturgiczno-pastoralne na przykładzie diecezji tarnowskiej; promotor: ks. prof. dr hab. Józef Stala; recenzenci: bp dr hab. Wojciech Osial (PwT Warszawa) i ks. dr hab. Stanisław Garnczarski (U PJPII w Krakowie, WTST): publiczna obrona odbyła się 16 grudnia 2016 r.

\section{Licencjaty}

ks. mgr Damian Kurek, Parafia Tymbark w latach 1918-1987; promotor: ks. prof. $\mathrm{dr}$ hab. Stanisław Sojka (praca magisterska zatwierdzona jako praca licencjacka) ks. mgr Karol Kuźma, Objawienia fatimskie w świetle wypowiedzi teologicznych po opublikowaniu trzeciej „tajemnicy fatimskiej”; promotor: ks. prof. dr hab. Stanisław Sojka

ks. mgr Grzegorz Nosal, Liturgia Wielkiego Czwartku; promotor: ks. prof. dr hab. Stanisław Sojka (praca magisterska zatwierdzona jako praca licencjacka)

ks. mgr Łukasz Plata, Cud w teologii fundamentalnej i misji Kościoła; promotor: ks. dr hab. Andrzej Michalik (praca magisterska zatwierdzona jako praca licencjacka)

mgr Elżbieta Serwińska-Kajmowicz, Wzrastanie Jezusa w Rodzinie Nazaretańskiej. Studium literacko-teologiczne ( $Ł k$ 2, 51-52); promotor: ks. dr hab. Piotr Łabuda ks. mgr Kamil Wróbel, Udział Kościoła w zwycięstwie Chrystusa nad Szatanem w świetle współczesnej literatury teologicznej; promotor: ks. dr hab. Marek Kluz

\section{Prace magisterskie}

Tomasz Bryndal, Misyjność Radia Diecezji Tarnowskiej - analiza struktury i programu z perspektywy historycznej 1993-2013; promotor: ks. dr hab. Michał Drożdż, prof. UPJPII 
Wojciech Cabak, Instytucja małżeństwa mieszanego w obecnym porządku prawnym Kościoła katolickiego; promotor: ks. prof. dr hab. Tomasz Rozkrut

Tomasz Chrupek, Wiedza i świadomość Jezusa z Nazaretu; promotor: ks. dr hab. Andrzej Michalik

Aldona Czerwiec, Kobieta w małżeństwie i rodzinie na podstawie dokumentu Konferencji Episkopatu Polski „Służyć prawdzie o małżeństwie i rodzinie”; promotor: ks. prof. dr hab. Józef Stala

Jakub Dobosz, Wieczerza w Emaus jako celebracja eucharystyczna. Studium literacko-teologiczne (Łk 24, 28-31); promotor: ks. dr hab. Piotr Łabuda

Krzysztof Dyrlik, Ocena życia społecznego zawarta w opracowaniu „Prawda Krzyż - Wyzwolenie" ks. Franciszka Blachnickiego; promotor: ks. dr hab. Ireneusz Stolarczyk, prof. UPJPII

Jarosław Gomułka, Charyzmat jako dar i zadanie w świetle publikacji zamieszczonych w „Zeszytach Odnowy w Duchu Świętym” (1994-2013); promotor: ks. prof. dr hab. Henryk Szmulewicz

Karol Góra, Zmartwychwstanie umarlych w świetle homilii na Triduum Paschalne („Biblioteka Kaznodziejska” 1963-2013); promotor: ks. prof. dr hab. Henryk Szmulewicz

Fabian Grębski, Wniebowzięcie Maryi jako udział w zmartwychwstaniu Chrystusa. Wspótczesne perspektywy teologiczne; promotor: ks. dr hab. Janusz Królikowski, prof. UPJPII

Roman Hopej, Naturalne prawo do klauzuli sumienia w zawodach medycznych. Analiza etycznych, prawnych i społecznych aspektów zagadnienia $w$ kontekście nauczania Kościoła; promotor: ks. dr hab. Michał Drożdż, prof. UPJPII

Paulina Jaje, Wplyw przymusu i bojaźni na zawarcie małżeństwa kanonicznego na podstawie wybranych wyroków Sądu Diecezjalnego w Tarnowie; promotor: ks. dr hab. Robert Kantor

Angela Kapustka, Pieśni do Najświętszego Serca Pana Jezusa w wybranych śpiewnikach polskich; promotor: ks. dr hab. Stanisław Garnczarski

Antoni Król, Jałmużna w nauczaniu duszpasterskim św. Bazylego Wielkiego, św. Ambrożego i św. Jana Chryzostoma; promotor: ks. prof. dr hab. Antoni Żurek

Karolina Krużel, Problematyka łaski w katechizmach dla szkół ponadgimnazjalnych $w$ świetle nauczania Katechizmu Kościoła Katolickiego; promotor: ks. dr Czesław Noworolnik

Oskar Leśniak, Koncepcja Boga w filozofii Stanisława Lema; promotor: ks. prof. dr hab. Stanisław Wszołek 
Anna Leżoń, Rodzina zastępcza forma pomocy dla opuszczonego dziecka; promotor: ks. dr hab. Marek Kluz

Grzegorz Łabędzki, Teologia rodziny w nauczaniu papieża Benedykta XVI; promotor: ks. dr hab. Marek Kluz

Jan Maciuszek, Aretologiczny wymiar duchowości Stefanii Łąckiej; promotor: ks. dr Adam Kokoszka

S. Małgorzata Marcinek, Tajemnica ojcostwa Świętego Józefa. Studium literacko-egzegetyczne (Łk 2, 41-52); promotor: ks. dr hab. Piotr Łabuda

Mateusz Norek, Ideał duchownego i mnicha w świetle Dialogów Grzegorza Wielkiego; promotor: ks. prof. dr hab. Antoni Żurek

Kamil Pawlik, Diecezjalna Rada do spraw ekonomicznych w pasterskiej postudze biskupa; promotor: ks. prof. dr hab. Tomasz Rozkrut

Piotr Pietrucha, Religijność a akceptacja własnej niepełnosprawności. Badania empiryczne osób z niepełnosprawnością ruchową; promotor: ks. dr Andrzej Sułek Łukasz Pietrzak, Uczucia Jezusa z Nazaretu; promotor: ks. dr hab. Andrzej Michalik Norbert Sadko, Matka Miłosierdzia. Geneza i aktualna interpretacja tytułu maryjnego; promotor: ks. dr hab. Janusz Królikowski, prof. UPJPII

Michał Sapalski, Apologia religii i chrześcijaństwa w wybranych dziełach C.S. Lewisa; promotor: ks. dr hab. Andrzej Michalik

Dawid Stańczyk, Rozwój i wychowanie dziecka z niepetnosprawnościa intelektualna $w$ rodzinie na podstawie nauczania Kościoła ze szczególnym uwzględnieniem zaleceń Kongresu Papieskiej Rady ds. Rodziny z 1999 roku na temat: Rodzina a integracja osób niepelnosprawnych $w$ dzieciństwie i wieku dorastania; promotor: ks. prof. dr hab. Józef Stala

Joanna Szwalec, Samobójstwo a poczucie osamotnienia u młodzieży; promotor: ks. dr Andrzej Sułek

Damian Śliwa, Oczekiwanie paruzji w drugiej mowie św. Piotra. Analiza literacko-teologiczna $D z$ 3, 19-21; promotor: ks. dr hab. Piotr Łabuda

Piotr Świerczek, Resentyment a przebaczenie. Fryderyk Nietzsche wobec chrześcijaństwa; promotor: ks. prof. dr hab. Stanisław Wszołek

Piotr Trojan, Geneza kultu Matki Bożej Pocieszenia i jego przejawy w sanktuarium oo. Karmelitów w Pilźnie; promotor: ks. dr hab. Janusz Królikowski, prof. UPJPII Piotr Wąż, Prawda droga do wolności w życiu i nauczaniu bł. księdza Jerzego Popiełuszki; promotor: ks. dr hab. Ireneusz Stolarczyk, prof. UPJPII

Dawid Włodarczyk, Oczekiwania penitentów pod adresem spowiednika w kwestii pokonywania lęku w kontekście sakramentu pokuty i pojednania. Badania empiryczne; promotor: ks. dr Andrzej Sułek 
Mirosław Jasnosz cor, Czas i przestrzeń w filozofii i fizyce Izaaka Newtona; promotor: ks. dr hab. Tadeusz Pabjan

Michał Witek cor, Rytuał wypędzenia kozła jako istotny element Dnia Pojednania. Studium literacko-teologiczne Kpł 16, 20-22; promotor: ks. dr Mirosław Łanoszka Małgorzata Wróbel, Strój kobiety podczas modlitwy. Studium literacko-teologiczne 1 Kor 11, 1-16; promotor: ks. dr hab. Piotr Łabuda 